\title{
PENAMBAHAN BESAR SUDUT INKLINASI INSOLE SEPATU KERJA MENURUNKAN KADAR GLUKOSA DARAH PUASA DAN HbA1c
}

\section{(Insole Inclination of Work Shoes Decrease Fasting Blood Glucose and HbA1c Level)}

\author{
Herdianty Kusuma*, Ahmad Abdullah", Bambang Purwanto ${ }^{* *}$, Suhartatik $^{* * *}$ \\ *Program Studi Magister Ilmu Kesehatan Olahraga Fakultas Kedokteran Universitas Airlangga \\ *** Departemen Ilmu Faal Fakultas Kedokteran Universitas Airlangga \\ *** Departemen Biokimia Fakultas Kedokteran Universitas Airlangga \\ J1. Prof. Dr. Moestopo 47, Surabaya, 60131 \\ Email: kusuma.herdianty@gmail.com
}

\begin{abstract}
ABSTRAK
Pendahuluan: Lari downhill dapat memperbaiki ekspresi Glut-1 otot dan kadar glukosa darah puasa mencit. Kontraksi eksentrik pada lari downhill juga ditemukan pada kegiatan keseharian seperti menuruni tangga dan berjalan jinjit. Kegiatan menuruni tangga dan berjalan jinjit tidak mudah dilakukan berulang, tunggal, stabil dan universal, sehingga posisi jinjit pada kegiatan menuruni tangga digantikan dengan pemakaian insole pada sepatu yang digunakan untuk beraktivitas. Tujuan penelitian ini adalah untuk mengetahui pengaruh penggunaan insole sepatu terhadap kadar glukosa darah puasa dan HbA1c. Metode: Penelitian ini menggunakan experimental pre and post tes design dengan subyek wanita pekerja sebanyak 12 orang di lingkungan Fakultas Kedokteran Universitas Airlangga selama 2 minggu dan dilakukan tes sebanyak tiga kali. Subjek diambil darah sebelum pemakaian insole sepatu dan setelah pemakaian insole sepatu. Insole sepatu yang dipakai memiliki perbedaan inklinasi $5^{0}$ dan $10^{\circ}$. Setiap subjek menggunakan insole sepatu selama 1 minggu. Hasil: Data hasil penelitian menunjukkan kadar glukosa darah puasa (GDP) dan HbA1c subjek yang memakai insole sepatu lebih rendah dibandingkan dengan kelompok kontrol. Kadar glukosa darah puasa (GDP) dan HbA1c subjek yang memakai insole $10^{0}$ memiliki nilai p < 0,05. Diskusi: Pemakaian insole sepatu menyebabkan penurunan kadar glukosa darah puasa (GDP) dan HbA1c.
\end{abstract}

Kata kunci: insole sepatu, glukosa darah puasa (GDP), HbA1c, diabetes, eksentrik.

\begin{abstract}
Introduction: Running downhill improved the expression of glucose transporter 1 (Glut 1) and fasting blood glucose in mouse. Eccentric contraction during running downhill found daily in activity such as down stairs and walking on tiptoe. Descend the stairs and walking on tiptoe are not easy to repeated, single, stable and universal, so that we purposed to replace it with additional insole in shoes for daily activity. The aim of this research was to investigate the effect of the additional shoe insole on fasting blood glucose and HbAlc. Method: This research using experimental pre and post test design with 12 subject female staff at Medical Faculty of Airlangga University for two weeks and the test was performed in three times. The blood was taken before and after using shoe insole. The shoe insole inclination designed into $5^{\circ}$ and $10^{\circ}$. All subjects used the shoe insole for a week. Result: The result research showed the fasting blood glucose and HbAlc on subject that use shoe insole lower than control group. The fasting blood glucose and HbAlc on subject that use shoe insole $10^{\circ}$ has value p<0,05. Discussion: Application of shoe insole lead to reduce the fasting blood glucose and HbAlc.
\end{abstract}

Keywords: shoe insole, fasting blood glucose, HbAlc, diabetes, eccentric.

\section{PENDAHULUAN}

Diabetes mellitus merupakan gangguan metabolisme karbohidrat, lemak dan protein yang disebabkan penurunan sekresi insulin atau penurunan sensitivitas jaringan terhadap insulin (Hall 2015). Perbandingan diabetes mellitus pada orang dewasa dengan usia 20 sampai 79 tahun di dunia mencapai 6,4\% pada tahun 2010 dan akan meningkat menjadi $7,7 \%$ pada tahun 2030 (Shaw dalam Muktabhant et al. 2012). Oleh karena itu diperlukan upaya untuk mengobati penderita diabetes mellitus, salah satunya dengan melakukan aktivitas fisik untuk meningkatkan sensitivitas terhadap insulin.
Salah satu aktivitas kontraksi eksentrik dapat terjadi saat lari menuruni bukit (lari downhill) yang diketahui dapat memperbaiki ekspresi Glut-1 otot dan kadar glukosa darah puasa pada mencit. Pada aktivitas keseharian kontraksi eksentrik ternyata juga terjadi saat berjalan menuruni tangga dan berjalan jinjit, tetapi aktivitas seperti ini tidak selalu dilakukan apalagi dalam waktu yang lama. Untuk mengetahui pengaruh kontraksi eksentrik dalam aktivitas keseharian maka posisi jinjit sambil menuruni tangga digantikan dengan memakai insole sepatu.

Insole sepatu adalah bagian dalam dari sepatu yang terletak di bawah kaki yang 
merupakan titik kontak antara kaki dengan tanah. Pada kondisi diabetes, insole sepatu dapat digunakan untuk memberikan kenyamanan dan melindungi kaki dari mikro trauma (Uccioli \& Giacomozzi 2009).

Pemakaian insole sepatu didesain untuk menghasilkan kontraksi eksentrik dalam waktu yang cukup lama yaitu saat aktivitas bekerja. Insole sepatu ini memiliki ketinggian $5^{0}$ dan $10^{0}$ pada bagian belakang. Ketinggian sudut menyebabkan unloading lebih cepat pada bagian belakang kaki saat berjalan dan memuat beban lebih besar pada ujung metatarsal. Di sisi lain, peningkatan ketinggian insole sepatu dapat menyebabkan pemendekan pada tendon Achilles yang dapat mengurangi daya ledak dari otot kaki. Oleh karena itu ketinggian insole sepatu yang umum adalah sekitar 1,5-3cm dari tanah (Rossi dalam Uccioli \& Giacomozzi 2009).

Kontraksi eksentrik merupakan kontraksi yang terjadi ketika serabut otot mengalami perubahan panjang. Kontraksi ini merupakan lawan dari kontraksi konsentrik sehingga disebut juga kontraksi negatif. Pemakaian energi selama kontraksi eksentrik ini membutuhkan oksigen dan cadangan energi lebih sedikit dibanding kontraksi konsentrik, sehingga untuk aktivitas seperti berlari atau berjalan menuruni bukit mampu memperbaiki daya tahan otot lebih efektif karena kelelahan otot terjadi lebih lambat (Kisner \& Colby 2007).

Penelitian ini bertujuan untuk mengetahui pengaruh pemakaian insole model aktivitas eksentrik terhadap kadar glukosa darah puasa dan $\mathrm{HbAlc}$. Kadar glukosa darah puasa (GDP) dan HbAlc merupakan pemeriksaan untuk mengetahui seseorang memiliki riwayat penyakit diabetes atau tidak. Pemeriksaan ini dilakukan dengan cara mengambil sampel darah. Berdasarkan kriteria dari American Diabetes Association (ADA) kadar glukosa darah puasa (GDP) $126 \mathrm{mg} / \mathrm{dl}$ atau lebih didiagnosa sebagai diabetes mellitus tipe 2 (WHO dalam Veghari et al. 2014). Nilai HbA1c pada orang non diabetes antara $20-42 \mathrm{mmol} / \mathrm{mol}$ atau setara dengan 4-6\%. Sedangkan pada orang diabetes nilainya sedikit lebih tinggi dibanding nilai tersebut (Diabetes Federation of Ireland 2010).

\section{BAHAN DAN METODE}

Penelitian ini merupakan penelitian eksperimental dengan menggunakan pre and post test design yang akan membandingkan efek penggunaan insole $5^{\circ}$ dan $10^{\circ}$ terhadap kadar glukosa darah (GDP) dan HbAlc.

Bahan yang dipakai dalam penelitian ini adalah insole sepatu dengan ketinggian $5^{0}$, sepatu standart dengan ketinggian insole $5^{0}$ dan sampel darah subyek untuk mengetahui kadar glukosa darah puasa (GDP) dan HbA1c.

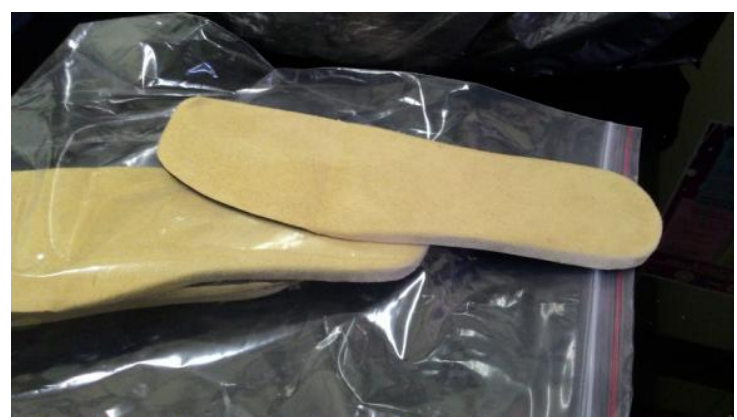

Gambar 1. Insole sepatu 5 derajat

Subyek penelitian adalah karyawan wanita di lingkungan Fakultas Kedokteran Universitas Airlangga non diabetes mellitus sebanyak 12 orang yang bersedia menandatangani inform consent. Setelah dilakukan pengukuran berupa tinggi badan, berat badan, lingkar perut dan ukuran sepatu subyek dilakukan pre test dengan cara pengambilan darah melalui intra vena oleh analis yang berpengalaman setelah subyek berpuasa selama 10 jam. Kemudian subyek dibagi menjadi 3 kelompok, yaitu kelompok kontrol, kelompok pemakaian insole $5^{0}$ dan kelompok pemakaian insole $10^{\circ}$. Kelompok kontrol merupakan kelompok sebelum diberikan perlakuan berupa pemakaian insole $5^{0}$ maupun $10^{\circ}$. Pemakaian insole $5^{0}$ dan $10^{\circ}$ ini pada masing-masing kelompok dilakukan selama 5 hari kerja.

Proses penelitian ini dilakukan pada bulan Mei-Juni 2015 di Fakultas Kedokteran Universitas Airlangga. Setelah dilakukan pre test subyek menggunakan sepatu standar dengan ketinggian sudut insole sepatu $5^{0}$ selama 5 hari kerja. Kemudian pada hari ke tujuh dilakukan tes kedua. Setelah itu subyek diberi tambahan insole sepatu $5^{0}$ sehingga ketinggian insole menjadi $10^{0}$ selama 5 hari kerja. Kemudian pada hari ke empat belas dilakukan tes ketiga. Setiap selesai melakukan tes, sampel darah dibawa ke laboratorium untuk diketahui kadar glukosa darah puasa (GDP) dan HbA1c. 


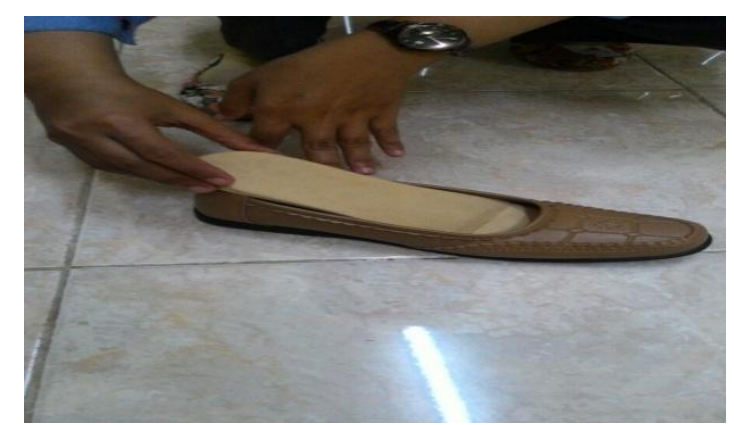

Gambar 2. Aplikasi insole sepatu tambahan ke dalam sepatu kerja

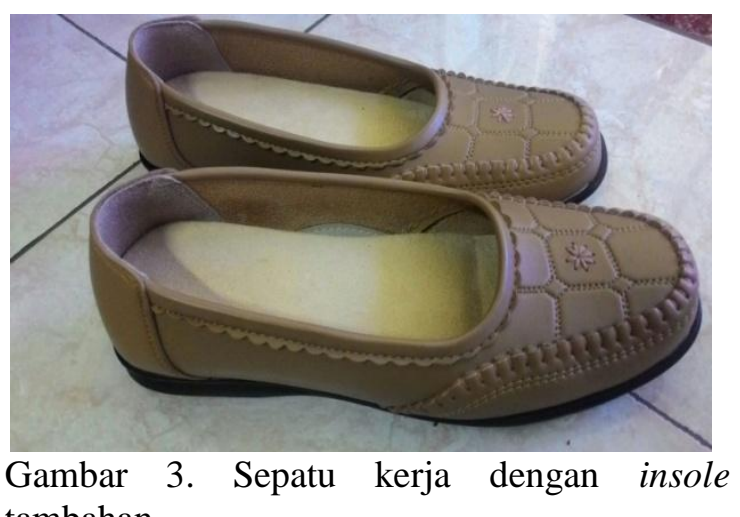

tambahan

Selama penelitian pola makan pada subyek dikendalikan dan dilakukan pemantauan kondisi subyek selama beraktivitas menggunakan insole sepatu. Dari 12 subyek terdapat 4 subyek yang drop out karena tidak mampu melanjutkan penelitian.

\section{HASIL}

Setelah dilakukan analisis data diketahui hasil uji normalitas pada kadar glukosa darah puasa kelompok kontrol nilai $p=0,05$, kelompok pemakaian insole sepatu 5 derajat nilai $p=0,96$ dan kelompok pemakaian insole sepatu 10 derajat nilai $p=0,266$. Sedangkan hasil uji normalitas pada kadar HbA1c kelompok kontrol nilai $p=0,59$, kelompok pemakaian insole 5 derajat $p=0,748$ dan kelompok pemakaian insole sepatu 10 derajat $p=0,60$. Dari semua hasil tersebut disimpulkan nilai $p>0,05$, maka semua data tersebut adalah normal. Kemudian dilakukan analisis data uji beda menggunakan one way anova diketahui kadar glukosa darah puasa (GDP) memiki nilai $p=0,005$, sedangkan HbA1c memiliki nilai $p=0,022$. Hal tersebut menunjukkan terdapat penurunan kadar glukosa darah puasa (GDP) dan HbA1c yang bermakna antara sebelum dan setelah pemakaian insole sepatu. Penurunan kadar glukosa darah puasa (GDP) dan $\mathrm{HbA1c}$ antara pemakaian insole sepatu $5^{0}$ dan $10^{0}$ menunjukkan hasil yang lebih bermakna pada pemakaian insole sepatu $10^{\circ}$.

Tabel 1. Rerata dan standar deviasi kadar GDP pada kelompok kontrol, kelompok pemakaian insole $5^{0}$ dan kelompok pemakaian insole $10^{0}$

\begin{tabular}{ll}
\hline Kelompok & Rerata \pm SD \\
\hline Kontrol & $80,5 \pm 14,313^{\mathrm{a}}$ \\
Insole $5^{0}$ & $76 \pm 13,79^{\mathrm{a}}$ \\
Insole $10^{\circ}$ & $59,38 \pm 6,52^{\mathrm{b}}$ \\
\hline
\end{tabular}

Pada tabel tersebut superscript yang berbeda menunjukkan nilai $\mathrm{p}<0,05$ yang berarti bahwa kelompok insole sepatu $10^{0}$ lebih bermakna terhadap penurunan kadar glukosa darah puasa (GDP).

Tabel 2. Uji beda kadar GDP antar kelompok

\begin{tabular}{lll}
\hline \multicolumn{1}{c}{ Kelompok } & Pembanding & \multicolumn{1}{c}{ Nilai p } \\
\hline Kontrol & $\begin{array}{l}\text { Insole 5 } \\
\text { derajat }\end{array}$ & 0,464 \\
\cline { 2 - 3 } & $\begin{array}{l}\text { Insole } 10 \\
\text { derajat }\end{array}$ & $0,002^{*}$ \\
\hline $\begin{array}{l}\text { Insole 5 } \\
\text { derajat }\end{array}$ & $\begin{array}{l}\text { Insole 10 } \\
\text { derajat }\end{array}$ & $0,012^{*}$ \\
\hline
\end{tabular}

Berdasarkan data antara kelompok kontrol dengan kelompok insole $5^{0}$ tidak memiliki perbedaan yang bermakna $(\mathrm{p}=0,464)$, tetapi antara kelompok kontrol dengan kelompok insole $10^{0}$ terdapat perbedaan bermakna $(\mathrm{p}=0,002)$. Sedangkan antara kelompok insole $5^{\circ}$ dan $10^{\circ}$ terdapat perbedaan yang bermakna $(p=0,012)$. Hal ini menunjukkan bahwa ada perbedaan yang bermakna pada kelompok pemakaian insole $10^{0}$

Tabel 3. Rerata dan standar deviasi kadar HbA1c pada kelompok kontrol, kelompok pemakaian insole $5^{0}$ dan kelompok pemakaian insole $10^{\circ}$

\begin{tabular}{ll}
\hline Kelompok & Rerata \pm SD \\
\hline Kontrol & $5,337 \pm 0,4926^{\mathrm{a}}$ \\
Insole $5^{0}$ & $4,862 \pm 0,4719^{\mathrm{a}}$ \\
Insole $10^{0}$ & $4,650 \pm 0,4209^{\mathrm{b}}$ \\
\hline
\end{tabular}

Pada tabel tersebut superscript yang berbeda menunjukkan nilai $\mathrm{p}<0,05$ yang 
berarti bahwa kelompok insole sepatu $10^{0}$ lebih bermakna terhadap penurunan kadar HbAlc.

Tabel 4. Uji beda kadar HbA1c antar kelompok

\begin{tabular}{lll}
\hline Kelompok & Pembanding & Nilai p \\
\hline Kontrol & $\begin{array}{l}\text { Insole 5 } \\
\text { derajat }\end{array}$ & 0,053 \\
\cline { 2 - 3 } & $\begin{array}{l}\text { Insole } 10 \\
\text { derajat }\end{array}$ & $0,007^{*}$ \\
\hline $\begin{array}{l}\text { Insole 5 } \\
\text { derajat }\end{array}$ & $\begin{array}{l}\text { Insole 10 } \\
\text { derajat }\end{array}$ & 0,369 \\
\hline
\end{tabular}

*Nilai $\mathrm{p}<0,05$ menunjukkan perbedaan yang bermakna

Berdasarkan data antara kelompok kontrol dengan kelompok insole $5^{0}$ tidak memiliki perbedaan yang bermakna $(\mathrm{p}=0,053)$, tetapi antara kelompok kontrol dengan kelompok insole $10^{0}$ terdapat perbedaan bermakna $(\mathrm{p}=0,007)$. Sedangkan antara kelompok insole $5^{0}$ dan $10^{\circ}$ tidak terdapat perbedaan yang bermakna $(\mathrm{p}=0,369)$. Hal ini menunjukkan bahwa ada perbedaan yang bermakna pada kelompok pemakaian insole $10^{\circ}$ terhadap penurunan kadar $\mathrm{HbA} 1 \mathrm{c}$.

\section{PEMBAHASAN}

Pemakaian insole sepatu model aktivitas eksentrik terbukti dapat menurunkan kadar glukosa darah puasa (GDP) dan HbA1c secara bermakna pada wanita pekerja di lingkungan Fakultas Kedokteran Universitas Airlangga. Penggunaan insole sepatu yang tinggi dapat mengurangi daya dorong dari ibu jari kaki, sehingga gerakan kaki saat berjalan lebih efisien daripada berjalan tanpa alas kaki atau dengan sepatu datar (Rossi dalam Uccioli \& Giacomozzi 2009). Hal inilah yang menjadi dasar untuk menerapkan aktivitas kontraksi eksentrik.

Kontraksi eksentrik merupakan kontraksi yang sering terjadi dalam aktivitas keseharian. Pada pemakaian insole sepatu selama aktivitas kerja kontraksi eksentrik terjadi karena otot berkontraksi sedangkan gaya dari luar berusaha untuk memanjangkan otot, sehingga kontraksi ini juga dapat digunakan untuk latihan meningkatkan kekuatan (Cluett 2014). Kontraksi eksentrik memiliki peran dalam meningkatkan performa. Saat terjadi kontraksi eksentrik tenaga maksimal yang dihasilkan tidak memberikan efek terhadap kecepatan pemanjangan otot, sedangkan pada kontraksi konsentrik meskipun otot memendek lebih cepat tetapi tenaga yang digunakan kurang maksimal. Sehingga tenaga yang lebih besar dihasilkan dari kontraksi eksentrik. Kontraksi eksentrik juga berperan dalam efisiensi mekanis dan penghematan energi. Menurut penelitian yang dilakukan oleh Komi, yang membandingkan penggunaan energi terhadap performa kerja, diketahui bahwa kerja akan lebih ekonomis jika diberikan gerakan yang meliputi siklus pemanjangan dan pemendekan (kontraksi eksentrik) dibandingkan hanya kontraksi konsentrik saja. Selanjutnya kemampuan otot untuk menyerap energi selama kontraksi eksentrik dapat digunakan untuk menghentikan gerakan dan memungkinkan melindungi komponen penting seperti tulang, kartilago dan ligamen dari kerusakan (Enoka 1996).

Penggunaan insole sepatu model aktivitas eksentrik yang digunakan dalam aktivitas kerja dapat berperan dalam meningkatkan performa, efisiensi dalam hal mekanis dan menghemat energi. Selain itu dapat menstimulasi kontraksi eksentrik dinamik pada otot gastrocnemius. Sehingga dapat membantu meningkatkan ekspresi dan kinerja Glut-1 dalam membantu ambilan glukosa.

Gangguan metabolisme karbohidrat, lemak dan protein pada diabetes mellitus dapat membaik yang ditandai dengan penurunan kadar glukosa darah puasa (GDP) dan $\mathrm{HbA1c}$ (Price \& Wilson 2006).

\section{SIMPULAN DAN SARAN}

\section{Simpulan}

Pemakaian insole sepatu $5^{0}$ dan $10^{\circ}$ memberikan pengaruh terhadap penurunan kadar glukosa darah puasa (GDP) dan HbA1c. Meskipun kedua model insole sepatu tersebut memberikan penurunan yang bermakna, tetapi model insole sepatu $10^{\circ}$ diketahui memberikan hasil yang lebih baik. Dengan demikian kontraksi eksentrik dengan memakai insole sepatu model aktivitas eksentrik terbukti dapat menurunkan kadar glukosa darah puasa (GDP) dan HbA1c, sehingga model ini dapat diterapkan untuk penderita diabetes mellitus.

\section{Saran}

Pada penelitian selanjutnya disarankan pemakaian insole sepatu model aktivitas eksentrik dapat diterapkan pada penderita 
diabetes mellitus untuk mengetahui efek terhadap kadar glukosa darah puasa (GDP) dan HbA1c.

\section{KEPUSTAKAAN}

'Diabetes Federation of Ireland', 2010. Diabetes Federation of Ireland Annual Report 2010, Available at: https://www.diabetes.ie/wpcontent/uploads/2014/11/Annual-Report2010-with-lay-summary-appendix.pdf.

Cluett, J., 2014. Eccentric Contraction. Available at: http://orthopedics.about.com/cs/sprainsstr ains/g/eccentric.htm.

Enoka, R.M., 1996. Eccentric contractions require unique activation strategies by the nervous system. Journal of applied physiology (Bethesda, Md. : 1985), 81(6), pp.2339-2346.

Hall, J.E., 2015. Guyton and Hall Textbook of Medical Physiology, Elsevier Health Sciences. Available at: https://books.google.co.id/books?id=krL SCQAAQBAJ.

Kisner, C. \& Colby, L.A., 2007. Therapeutic Exercise: Foundations and Techniques,
F.A. Davis. Available at: https://books.google.co.id/books?id=phtn QgAACAAJ.

Muktabhant, B. et al., 2012. Interventions for preventing excessive weight gain during pregnancy. The Cochrane database of systematic reviews, 4, p.CD007145.

Price, S.A. \& Wilson, L.M., 2006. Buku Patofisiologi: Konsep Klinis ProsesProses Penyakit Edisi 6 Volume 2 6th ed., EGC.

Uccioli, L. \& Giacomozzi, C., 2009. Biomechanics and choosing footwear for the diabetic foot. The Diabetic Foot Journal, 12(4), p.11. Available at: http://www.diabeticfootjournal.co.uk/jour nal-content/view/biomechanics-andchoosing-footwear-for-the-diabeticfoot/?preview.

Veghari, G. et al., 2014. The association of fasting blood glucose (FBG) and waist circumference in northern adults in Iran: a population based study. Journal of Diabetes and Metabolic Disorders, 13, p.2. Available at: http://www.ncbi.nlm.nih.gov/pmc/articles /PMC3937214/. 